\title{
Reduction of skull size in South American sea lions reveals density-dependent growth during population recovery
}

\author{
M. Drago ${ }^{1, *}$, L. Cardona ${ }^{1}$, E. A. Crespo ${ }^{2,3}$, M. F. Grandi ${ }^{2}$, A. Aguilar ${ }^{1}$ \\ ${ }^{1}$ Department of Animal Biology and Biodiversity Research Institute (IRBio), University of Barcelona, Avinguda Diagonal 645, \\ 08028 Barcelona, Spain \\ ${ }^{2}$ Laboratory of Marine Mammals, Centro Nacional Patagónico (CENPAT-CONICET), Blvd. Brown 2915, \\ 9120 Puerto Madryn, Chubut, Argentina \\ ${ }^{3}$ National University of Patagonia, Blvd. Brown 2825, 9120 Puerto Madryn, Chubut, Argentina
}

\begin{abstract}
Craniometrical data of male and female skulls collected from 1974 to 2007 were used to test the hypothesis that the somatic growth of South American sea lions Otaria flavescens in northern Patagonia has been affected by a reduction in the per capita food availability, due to a combination of the population recovery after cessation of sealing and the development of industrial fishing targeting Argentine hake Merluccius hubbsi. Most of the 19 craniometric variables considered decreased through time in both sexes, and the same trend was found for a variable extracted by means of principal component analysis that was related to skull volume. Most of the reductions in skull size and volume have happened since 1990, when the sea lion population peaked and the hake population collapsed. This evidence, combined with a review of supplementary data derived from stable isotope analysis, supports the hypotheses that the somatic growth of South American sea lions is densitydependent and that industrial fishing has reduced the carrying capacity of the ecosystem for South American sea lions.
\end{abstract}

KEY WORDS: Density-dependent growth · Somatic growth · Overfishing · Craniometry · South American sea lion · Otaria flavescens $\cdot$ Skull size $\cdot$ Argentine hake

Resale or republication not permitted without written consent of the publisher

\section{INTRODUCTION}

Density dependence is the very core of classic population ecology (Rockwood 2006), but testing for its presence in wild marine vertebrate populations has been extremely difficult. Although in some cases populations are actually well below carrying capacity and growth and demographic parameters are independent of population size (Doherty 2002), the most common situation is the inability of researchers to carry out the experiments required to test the predictions of density dependence (Hixon \& Webster 2002). Nevertheless, the past and present massive exploitation of large marine vertebrates (Myers \& Worm 2003, Lewison et al. 2004) offers the possibility of studying the response of these species to dramatic changes in population size. Changes in demographic parameters will often be impossible to document in the absence of data about the pre-exploitation period, but museum collections offer an opportunity to test predictions about the impact of population size on somatic growth.

Many otariid species were hunted to the brink of extinction throughout the 19th and 20th centuries due to commercial exploitation for their pelts and fat (Bonner 1982). After cessation of hunting, some species quickly recovered but others failed to do so, mainly in the Southern Ocean and adjoining regions (Trites 1992, Wickens \& York 1997, Gerber \& Hilborn 2001, National Research Council 2002, Costa et al. 2006). At least one of these species, the northern fur seal Callorhinus ursinus, exhibited strong density-dependent somatic growth during the recovery period that followed cessation of hunting (Scheffer 1955, Etnier 2004). A similar pattern has been suggested for male 
Antarctic fur seals Arctocephalus gazella in South Georgia, on the basis of the reduced width of tooth annulus in individuals from recent years (Hanson et al. 2009). On the other hand, reduced body size in Steller sea lions Eumetopias jubatus through the 1980s has been hypothesised to be the result of nutritional stress caused by changes in the ecosystem (Trites \& Donnelly 2003).

The South American sea lion Otaria flavescens was heavily exploited in the south-western Atlantic Ocean from the 1920s to the 1960s (Godoy 1963), with populations reduced to less than $10 \%$ of their original number by the time exploitation ceased (Crespo \& Pedraza 1991, Reyes et al. 1999, Schiavini et al. 2004). In Argentina, the recovery of the population only began in the early 1990s, after 3 decades of stagnation (Crespo \& Pedraza 1991, Reyes et al. 1999, Schiavini et al. 2004), and now the population is about one third of the original size (Reyes et al. 1999, Dans et al. 2004, Schiavini et al. 2004). Drago et al. (2009a) reported an increased reliance of South American sea lions on offshore, pelagic prey since the 1970 s, probably because of increased intraspecific competition at benthic foraging grounds as the population grew, which forced them to exploit more distant foraging grounds. Furthermore, Drago et al. (2009a) pointed out that massive fish discards by bottom trawlers, mainly undersized Argentine hake Merluccius hubbsi, may have resulted in increased accessibility to this particular demersalpelagic species. Although pelagic potential prey have a higher nutritional quality than benthic potential prey (Eder \& Lewis 2005, Drago et al. 2009a), the stock of Argentine hake has declined dramatically since the development of industrial fishing (Lloris et al. 2003, Koen Alonso \& Yodzis 2005) and the Magellanic penguins Spheniscus magellanicus, a potential competitor for small schooling fishes (Thompson 1989, Thompson et al. 1998, Schiavini et al. 2005), are now more abundant than ever (Carribero et al. 1995, Schiavini et al. 2005). These aforementioned factors raise some doubts about the prospects for the recovery of the South American sea lion population because the carrying capacity for the population in this new, highly anthropogenized ecosystem might be much lower than it was before the development of industrial fishing.

Assessing changes in the body size of South American sea lions throughout the 20th century is one possible way of understanding the correlations between somatic growth and the effects of limiting factors such as population density and prey availability, since mammal adult body size is positively correlated with food availability before puberty (Scheffer 1955) and body size is highly correlated with skeletal measurements in otariids (Scheffer 1950, Scheffer \& Wilke 1953, Rosas et al. 1993, Miller et al. 2000). Furthermore, skeletal mea- surements are easily standardized and thereby measurement errors are minimized.

The present study investigates how population recovery after cessation of sealing and the development of industrial fishing have affected the size of South American sea lions in northern Patagonia. The hypothesis to be tested is the existence of an inverse correlation between somatic growth and population density because of decreasing per capita food availability.

\section{MATERIALS AND METHODS}

Sampling. A total of 194 skulls of South American sea lions (92 males and 102 females) from the scientific collection of the Centro Nacional Patagónico (CENPAT) at Puerto Madryn, Argentina, were examined to determine size changes during the last 4 decades. All the skulls had been cleaned by dermestid beetles, then boiled to eliminate the remaining fat and flesh, washed with water and soap and finally stored dry. The skulls taken into consideration belonged to specimens that had been accidentally captured by fishermen or stranded dead along the coast of the heavily fished area off the Chubut province, in northern Patagonia (Fig. 1)

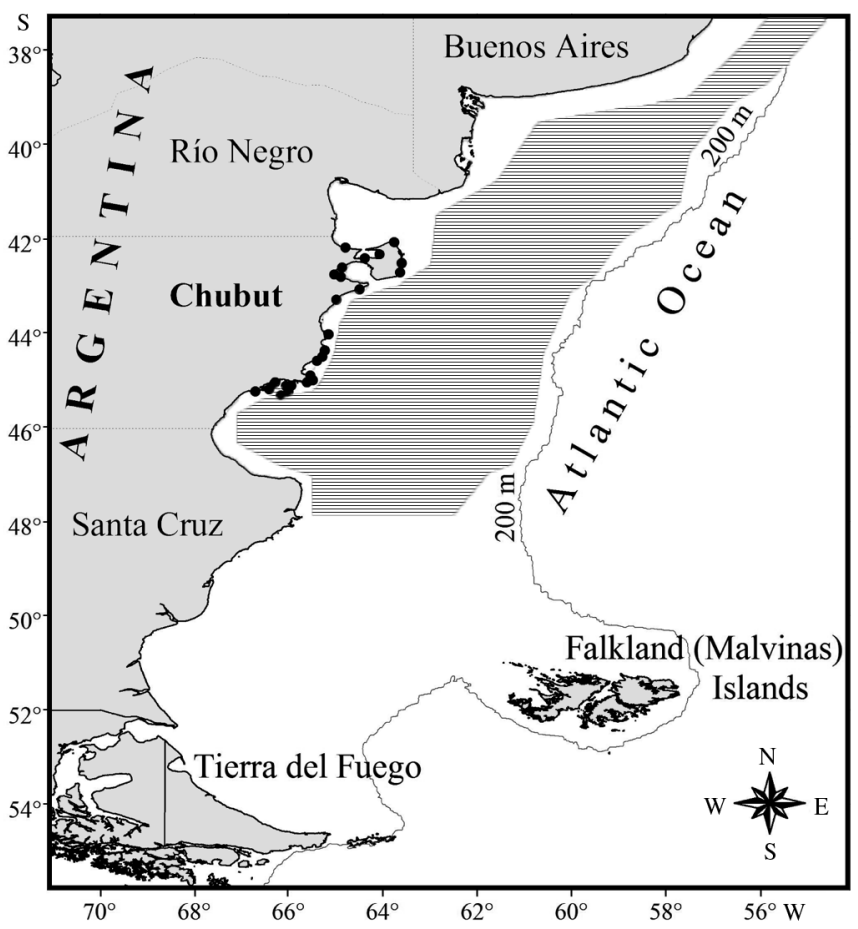

Fig. 1. Atlantic coast of Argentina and location of the Chubut province. The solid black circles $(\bullet)$ show the sampling location of South American sea lions Otaria flavescens. The hatching shows the fishing grounds exploited by the Argentine industrial fishing fleet in the second half of the 1980s and in the 1990s (Giangiobbe et al. 1993, Dato et al. 2003) 
from 1974 to 2007 . This time window included 3 periods of contrasting availability of the principal prey (Argentine hake) for South American sea lions in the area (Koen Alonso et al. 1996, Bertolotti et al. 2001, Dans et al. 2003, Lloris et al. 2003, Koen Alonso \& Yodzis 2005) (Fig. 2a,b). The 1960s and 1970s (1960-1980) were characterized by high hake availability, as indicated by a very large estimated hake biomass and a very small population of the South American sea lion. After the 1970s (1981-1997) hake availability began to decline, as indicated by the trend in estimated hake biomass. The latest years (1998-2002) were marked by a recovery of the South American sea lion population as well as the collapse of the hake fishery.

Skull size is highly correlated with body size in South American sea lions (Rosas et al. 1993) and remains almost invariable after 7 or 8 years of age for males and 5 or 7 years of age for females (Rosas et al. 1993, Drago et al. 2009b, Grandi et al. 2010). Hence only skulls from adult individuals of known age were used to avoid any age-related bias. The specimens were aged by counting growth layers in the dentine of the canines (Crespo 1988, Crespo et al. 1994). The age of the selected individuals ranged from 8 to 19 years for males and from 7 to 20 years for females. Errors in age determination are assumed to be similar through the considered time window and thus should not bias the results significantly. Nineteen linear measurements were made on the cranium and mandible of each skull (Fig. 3) with calipers (accuracy $\pm 0.1 \mathrm{~mm}$ ) by only one person (M. Drago) to avoid inter-observer errors. These measurements were selected according to the most influential dimension variables for the 2 pinniped species considered by Amano et al. (2002) and Brunner (2002). The standard body length (SL) of 49 specimens (20 males and 29 females) collected from 1990 to 2006 was
Fig. 2. (a) Argentine hake Merluccius hubbsi landings (from Dans et al. 2003) and biomass (from Koen Alonso \& Yodzis 2005); (b) Trajectory of the South American sea lion Otaria flavescens population in northern and central Patagonia estimated by means of a simple simulation model fitted by maximum likelihood (from Koen Alonso et al. 1996); (c) Trajectory of the average factor score of Component I (Factor I: see Table 2) related to the skull volume of female and male sea lions from Chubut Province in 3 contrasting periods (1960-1980; 1981-1997; 1998-2002). For each sex, periods with different letters (males) or Roman numerals (females) differ in their mean values according to the Student-NewmanKeuls post hoc test. Sample sizes: females, $\mathrm{n}=16,57,17$ for the first, second and third period respectively; males, $\mathrm{n}=15,38,15$ for first, second and third period respectively. The year associated with each Factor I value is the median of each sampling period. Error bars: SD
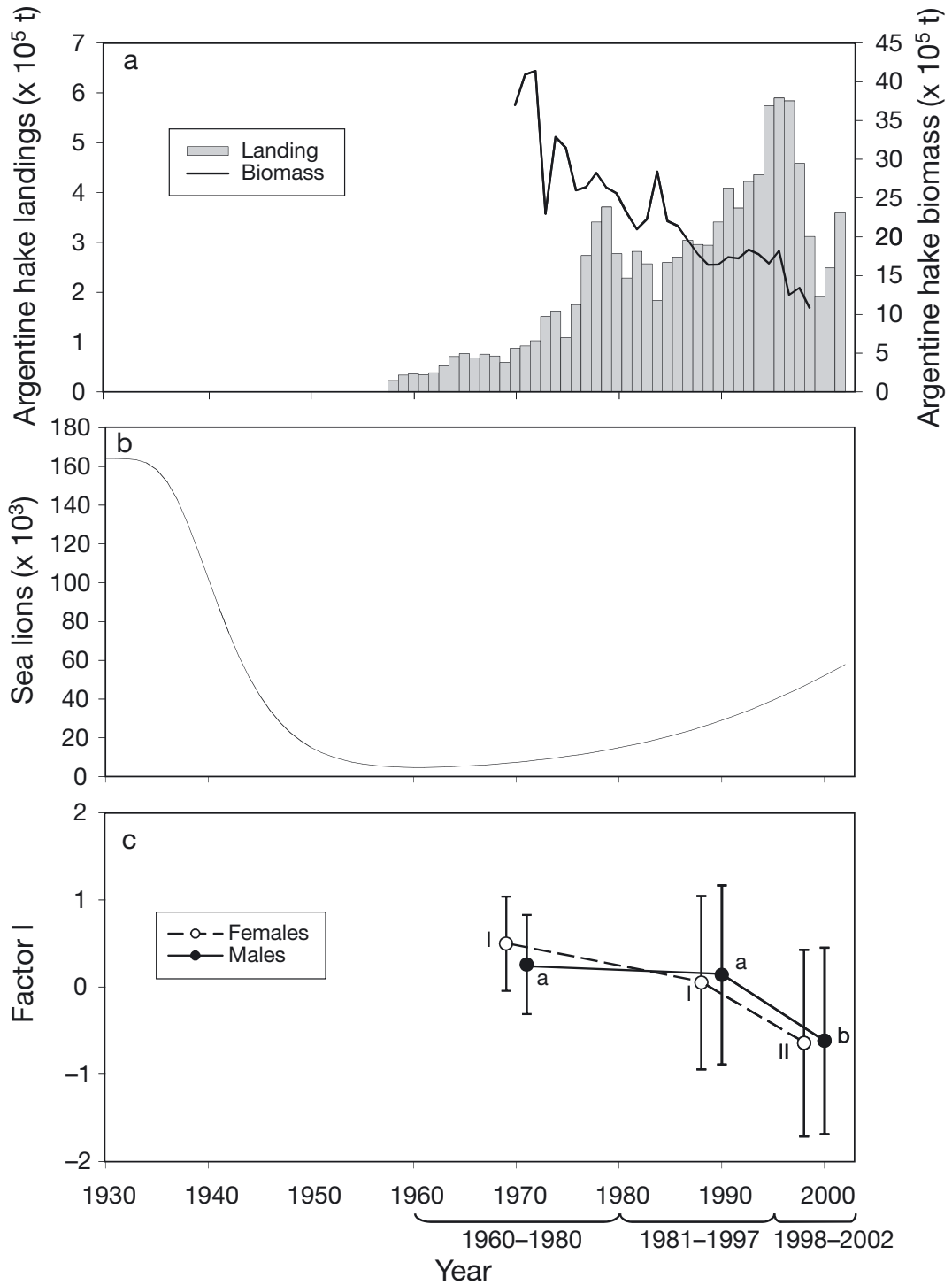

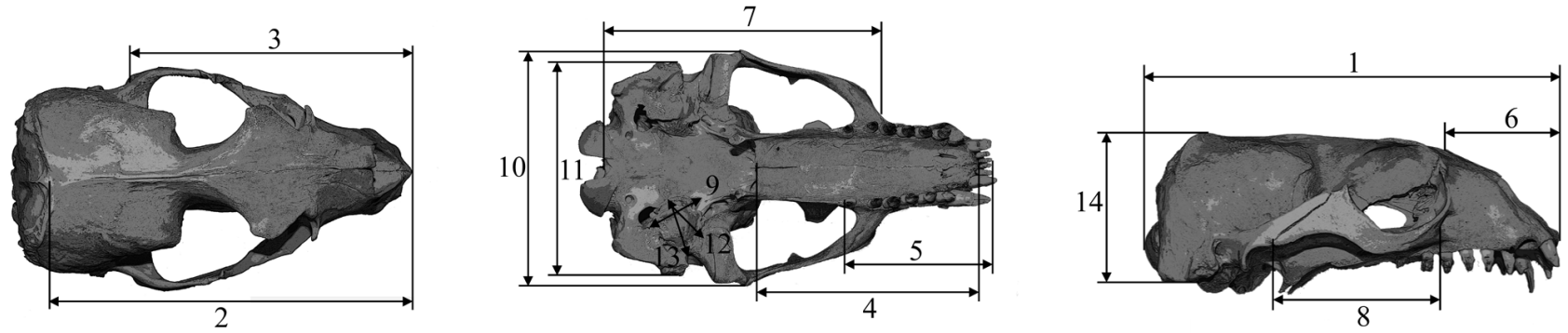

Fig. 3. Otaria flavescens. Dorsal, ventral and right lateral perspectives of the adult female South American sea lion skull showing measurements taken in the present study: 1: condylobasal length (CBL); 2: gnathion-to-occipital crest middle length (GOCL); 3: gnathion-to-caudal postglenoid process border length (GPPL); 4: palatal length (PL); 5: maxillary tooth row length (MaxTL); 6: snout length from posterior nasal margin (SL); 7: basion-to-zygomatic root length (BZRL); 8: zygomatic length (ZL); 9: bulla length (BL); 10: zygomatic width (ZW); 11: mastoid width $(\mathrm{MW}) ; 12$ : bulla average width $(\mathrm{BAW}) ; 13$ : bulla maximum width (BMW); 14: cranium height $(\mathrm{CH})$; 15: mandible length (ML); 16: mandibular tooth row length (ManTL); 17: masseteric fossa length (MFL); 18: masseteric fossa width (MFW); 19: mandible height (MH)

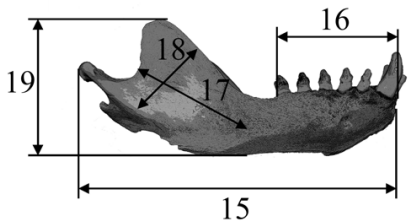

also measured and used to evaluate any change in the relationship between skull length (condylobasal length: CBL) and body length. SL was measured according to standard methods of the Committee on Marine Mammals (1967).

Data analyses. Males and females were analyzed separately because of the marked sexual dimorphism of South American sea lions (Rosas et al. 1993, Sanfelice \& De Freitas 2008, Drago et al. 2009b). The stability of the CBL/SL ratio through time within each sex was tested by linear regression analysis, whereas the influence of birth year on each craniometrical variable was tested using the non-parametric Spearman's $\rho$ correlation coefficient. Principal component analysis (PCA) was used to investigate the sources of morphological variation within each sex and to reduce the number of original variables to a few principal components. Prior to PCA the values for the original variables had been standardized, so that each variable had equal weighting and biases resulting from larger measurements dominating the smaller ones were removed. Extracted components were ordered in terms of magnitude of their variances. The non-parametric Spearman's $\rho$ correlation coefficient was used again to test the correlation between the birth year and the factor score extracted by PCA, to investigate the time trends of different dimensional facets in the skull of adult male and female sea lions.

The birth year of each specimen was calculated by subtracting the age at death from the stranding or capture year. The year when somatic growth finished was calculated by adding 8 years to the birth year of males and 6 years to the birth year of females (Rosas et al. 1993, Drago et al. 2009b, Grandi et al. 2010). Each sea lion was allocated to one of the three aforementioned time periods based on its growth span. When the growth span included 2 time periods, the individual was assigned to the time period which encompassed the longest part of its growth span. The only individual whose growth span covered 2 periods equally (one of the females in the third period) was assigned to the most recent one. One-way ANOVA, followed by the Student-Newman-Keuls (SNK) post hoc test, was used to compare the principal factor score, extracted by PCA, of individuals of the same sex in the 3 considered periods.

Data are always shown as mean \pm standard deviation (SD), unless otherwise stated. All statistical analyses were conducted with the SPSS 15 software package. Prior to any statistical analysis, data were tested for the assumptions of normality and homogeneity of variances by a Lilliefors test and Levene's contrast test, respectively.

\section{RESULTS}

Birth year was negatively and statistically correlated with most of the analyzed craniometrical variables of females (Table 1). The most remarkable exception was the length of the tympanic bulla (variable 9), which increased with the birth year. Birth year was also negatively and statistically correlated with the craniometrical variables of males related to the cranium width and height, and also to the mandible length and height (Table 1). The variables related to the cranium length were uncorrelated with the birth year, although 2 of them, the GPPL (variable 3) and BZRL (variable 7), were on the verge of significance (see Fig. 3 for variable abbreviations). The same was true for the MFL (variable 17), related to the mandible length (Table 1). 
Table 1. Otaria flavescens. Results of the non-parametric Spearman's $\rho$ correlation test between birth year and the craniometrical variables of adult male and female South American sea lions: sample size (n), correlation coefficient $(\rho)$, significance level $(p)$. Significant values $($ at $p<0.05)$ in bold. For variable numbers and abbreviations see Fig. 3

\begin{tabular}{|c|c|c|c|c|c|c|c|c|}
\hline \multirow{2}{*}{$\begin{array}{l}\text { Skull region } \\
\text { Dimension }\end{array}$} & \multicolumn{2}{|c|}{ Variable } & \multirow{2}{*}{$\mathrm{n}$} & - & \multirow[b]{2}{*}{$\mathrm{p}$} & \multirow{2}{*}{$\overline{\mathrm{n}}$} & $-0^{1}$ & \multirow[b]{2}{*}{$\mathrm{p}$} \\
\hline & no. & abbr. & & $\rho$ & & & $\rho$ & \\
\hline \multicolumn{9}{|l|}{ Cranium } \\
\hline \multirow[t]{9}{*}{ Length } & 1 & CBL & 99 & -0.375 & $<0.001$ & 85 & -0.135 & 0.217 \\
\hline & 2 & GOCL & 99 & -0.307 & 0.002 & 85 & -0.086 & 0.434 \\
\hline & 3 & GPPL & 99 & -0.395 & $<0.001$ & 85 & -0.212 & 0.052 \\
\hline & 4 & PL & 99 & -0.324 & 0.001 & 85 & -0.154 & 0.159 \\
\hline & 5 & MaxTL & 99 & -0.147 & 0.146 & 85 & -0.008 & 0.941 \\
\hline & 6 & SL & 98 & -0.215 & 0.033 & 84 & -0.149 & 0.176 \\
\hline & 7 & BZRL & 99 & -0.243 & 0.015 & 85 & -0.187 & 0.086 \\
\hline & 8 & ZL & 99 & -0.435 & $<0.001$ & 85 & -0.154 & 0.160 \\
\hline & 9 & BL & 99 & 0.344 & $<0.001$ & 86 & -0.069 & 0.530 \\
\hline \multirow[t]{4}{*}{ Width } & 10 & ZW & 99 & -0.501 & $<0.001$ & 86 & -0.461 & $<0.001$ \\
\hline & 11 & MW & 99 & -0.322 & 0.001 & 86 & -0.339 & 0.001 \\
\hline & 12 & BAW & 99 & 0.068 & 0.501 & 86 & -0.124 & 0.255 \\
\hline & 13 & BMW & 99 & -0.284 & 0.004 & 86 & -0.291 & 0.007 \\
\hline Height & 14 & $\mathrm{CH}$ & 99 & -0.051 & 0.616 & 86 & -0.270 & 0.012 \\
\hline \multicolumn{9}{|l|}{ Mandible } \\
\hline \multirow[t]{3}{*}{ Length } & 15 & ML & 94 & -0.412 & $<0.001$ & 74 & -0.259 & 0.026 \\
\hline & 16 & ManTL & 94 & -0.124 & 0.232 & 74 & 0.005 & 0.969 \\
\hline & 17 & MFL & 94 & -0.352 & $<0.001$ & 76 & -0.204 & 0.078 \\
\hline Width & 18 & MFW & 94 & -0.160 & 0.123 & 75 & -0.078 & 0.505 \\
\hline Height & 19 & $\mathrm{MH}$ & 94 & -0.351 & 0.001 & 75 & -0.318 & 0.005 \\
\hline
\end{tabular}

sexes and a skull shortening in females as time passed, and confirmed the results of the statisticallysignificant correlations between birth year and analyzed craniometrical variables.

Furthermore, one-way ANOVA (females: $F_{2,87}=6.207, \mathrm{p}=0.003$; males: $F_{2,65}=4.070, \mathrm{p}=0.022$ ) and a SNK post hoc test conducted independently for each sex demonstrated that Factor I of both males and females decreased from the second to the third period, and that differences did not exist between the first and the second period for either sex (Fig. 2c). Therefore in both sexes the skull volume of sea lions from the third period was significantly smaller than that of sea lions from the 2 previous periods considered here. As the CBL/SL ratio of both sexes did not change through time from 1990 to 2006 (females: $p=0.467$; males: $p=0.089$ ), a reduction in skull size is expected to be associated with a reduction in body size.
PCA extracted 3 components for female skulls and 2 for male skulls (Table 2). Component I accounted for $55.6 \%$ and $64.4 \%$ of the total variance for female and male skulls respectively, and was related to the skull volume in both sexes as variables concerning the 3 spatial dimensions had a similar weight (Table 2). Component II accounted for a further $10.0 \%$ of the total variance for female skulls and $7.6 \%$ for male skulls and was primarily affected by variables concerning skull length (Table 2). Component III, significant only for female skulls, accounted for another further $5.4 \%$ of the total explained variance but was obscure in its interpretation.

Birth year was negatively and significantly correlated with the factor score of Component I (Factor I) in both sexes, and positively and significantly correlated with the factor score of Component II (Factor II) for females, but not for males (Fig. 4). Birth year was uncorrelated with the factor score of Component III (Factor III) for females ( $\mathrm{n}=90, \rho=$ -0.089 , $p=0.405)$. As Factor I increased with the skull volume and Factor II decreased with the skull length, these results suggest a general skull volumetric reduction in both
Table 2. Otaria flavescens. Component loading from principal component analysis for craniometrical variables of adult male and female South American sea lions. For variable numbers and abbreviations see Fig. 3

\begin{tabular}{|c|c|c|c|c|c|c|c|}
\hline \multirow{3}{*}{$\begin{array}{l}\text { Skull region } \\
\text { Dimension }\end{array}$} & \multicolumn{2}{|c|}{ Variable } & \multirow{2}{*}{\multicolumn{3}{|c|}{$\stackrel{\stackrel{9}{\text { Component }}}{\text { Com }}$}} & \multirow{2}{*}{\multicolumn{2}{|c|}{$\begin{array}{c}\sigma^{7} \\
\text { Component }\end{array}$}} \\
\hline & & abbr. & & & & & \\
\hline & & & I & II & III & & II \\
\hline \multicolumn{8}{|l|}{ Cranium } \\
\hline \multirow[t]{9}{*}{ Length } & 1 & CBL & 0.956 & -0.061 & 0.044 & 0.947 & -0.118 \\
\hline & 2 & GOCL & 0.830 & -0.105 & 0.023 & 0.786 & -0.102 \\
\hline & 3 & GPPL & 0.956 & -0.109 & 0.009 & 0.944 & -0.115 \\
\hline & 4 & PL & 0.922 & -0.118 & 0.036 & 0.932 & -0.170 \\
\hline & 5 & MaxTL & 0.702 & -0.310 & 0.045 & 0.663 & -0.181 \\
\hline & 6 & SL & 0.610 & -0.230 & 0.205 & 0.716 & -0.182 \\
\hline & 7 & BZRL & 0.882 & 0.140 & -0.062 & 0.916 & 0.065 \\
\hline & 8 & ZL & 0.820 & -0.077 & -0.010 & 0.886 & -0.098 \\
\hline & 9 & BL & 0.205 & 0.821 & -0.143 & 0.450 & 0.721 \\
\hline \multirow[t]{4}{*}{ Width } & 10 & ZW & 0.795 & -0.070 & 0.024 & 0.870 & 0.007 \\
\hline & 11 & MW & 0.840 & 0.088 & -0.064 & 0.857 & 0.114 \\
\hline & 12 & BAW & 0.247 & 0.724 & 0.544 & 0.539 & 0.603 \\
\hline & 13 & BMW & 0.610 & 0.356 & 0.441 & 0.801 & 0.327 \\
\hline Height & 14 & $\mathrm{CH}$ & 0.530 & 0.411 & -0.528 & 0.725 & 0.236 \\
\hline \multicolumn{8}{|l|}{ Mandible } \\
\hline \multirow{3}{*}{ Length } & 15 & ML & 0.950 & -0.127 & 0.002 & 0.917 & -0.212 \\
\hline & 16 & ManTL & 0.622 & -0.208 & 0.210 & 0.746 & -0.434 \\
\hline & 17 & MFL & 0.680 & -0.164 & -0.073 & 0.895 & -0.016 \\
\hline Width & 18 & MFW & 0.603 & 0.305 & -0.298 & 0.651 & -0.003 \\
\hline Height & 19 & $\mathrm{MH}$ & 0.815 & 0.041 & -0.196 & 0.784 & 0.111 \\
\hline \multicolumn{3}{|c|}{$\%$ total variance explained } & 55.6 & 10.0 & 5.4 & 64.4 & 7.6 \\
\hline
\end{tabular}



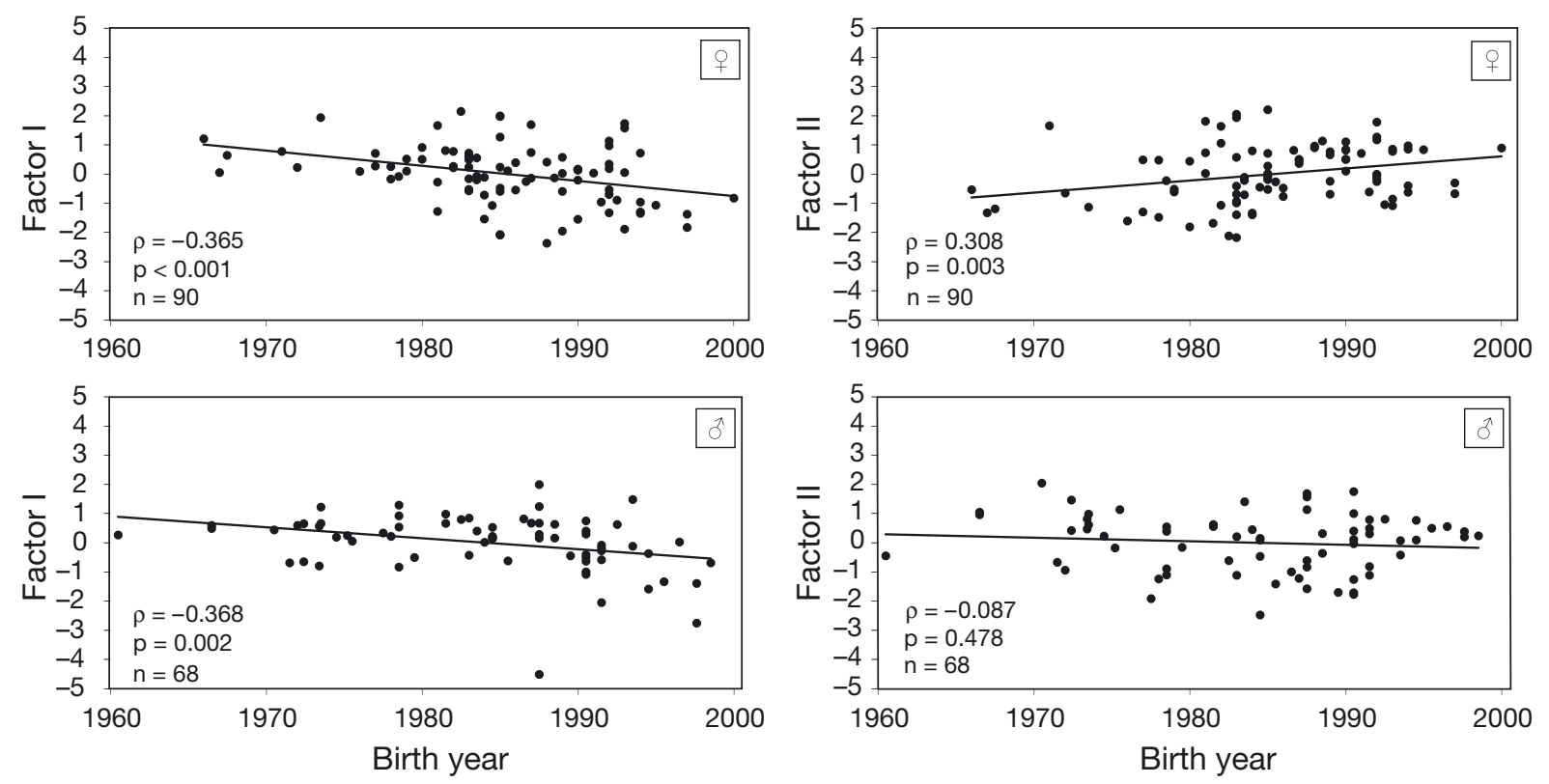

Fig. 4. Otaria flavescens. Non-parametric Spearman's $\rho$ correlation between birth year and the factor score for adult male and female South American sea lions. The sample size (n), correlation coefficient $(\rho)$, and significance level (p) are shown on each panel

\section{DISCUSSION}

The drastic reduction of the South American sea lion population due to commercial sealing was not the only human impact in the ecosystem off northern Patagonia through the 20th century, as in the 1970s a high sea fishery targeting Argentine hake Merluccius hubbsi was established there (Crespo et al. 1997, Bertolotti et al. 2001). The development of fishing has dramatically reduced the hake population (Lloris et al. 2003, Koen Alonso \& Yodzis 2005), which, combined with the extreme reduction of the sea lion population, has led to a severe reorganization of the whole ecosystem (Koen Alonso \& Yodzis 2005). The current ecosystem state is characterized by larger populations of Magellanic penguin Spheniscus magellanicus, Argentine short-fin squid Illex argentinus and Argentine anchovy Engraulis anchoita (Carribero et al. 1995, Koen Alonso \& Yodzis 2005, Schiavini et al. 2005). As a consequence, some former hake predators, such as the spiny dogfish Squalus acanthias, reduced their Argentine hake consumption as the stock declined and relied on alternative prey which had increased in abundance (Koen Alonso et al. 2002).

This reorganization of the ecosystem seems not to have prevented the recovery of the South American sea lion population in northern Patagonia, which is currently growing at an annual rate of about $6 \%$ (Dans et al. 2004). Furthermore, there has been a shift from a benthic-based diet in the 1970s to the current pelagic- based diet with a high contribution from Argentine hake (Drago et al. 2009a). Increased consumption of Argentine hake by the South American sea lion, at a time when the hake population has decreased, is a paradoxical result explained by 3 independent, nonexcluding mechanisms: (1) increased availability of juvenile hake due to cannibalism release, (2) increased consumption of discarded hake (from fisheries) by sea lions and (3) increased exploitation of pelagic feeding grounds due to increased intraspecific competition at benthic foraging grounds as the sea lion population has increased (Drago et al. 2009a).

Potential pelagic prey for South American sea lions off Patagonia have a higher nutritional value than potential benthic prey (Eder \& Lewis 2005, Drago et al. 2009a) and pups whose mothers have a primarily pelagic diet grow faster than those whose mothers have a primarily benthic diet (Drago et al. 2010a). As a consequence, the quality of the South American sea lion diet has probably improved as a result of increased consumption of pelagic prey since the 1970s (Drago et al. 2009a). However, the results presented here show that the largest average skull size was recorded when the South American sea lion population was at its historical minimum, and that somatic growth decreased as the hake stock declined and the South American sea lion population recovered. A similar pattern has been reported for several fur seal species, whereby somatic growth and the population size have long been known to be inversely correlated (Scheffer 1955, Etnier 2004, Hanson et al. 2009). 
Density dependence of somatic growth is ultimately caused by a reduction in the per capita prey abundance (Trites \& Bigg 1992). The skull reduction reported here thus indicates that the potential improvement in the diet quality caused by a shift to a more pelagic diet has not balanced the reduced per capita prey availability for South American sea lions. The per capita prey availability for South American sea lions may have decreased because of a larger population, a lower availability of the main prey target (hake) due to overfishing, or a combination of both.

South American sea lion pups grow more slowly during early lactation in bigger colonies than in smaller ones, perhaps due to a lower per capita food availability for females during this period (Drago et al. 2010b). Colony size has increased as the population of South American sea lions in northern Patagonia has recovered (Dans et al. 2004), thus leading to slower growth during early lactation. Under normal circumstances, it would be expected that this initial slower growth would eventually be counteracted by compensatory growth, a mechanism reported in a wide range of mammalian species, including several pinnipeds (Wilson \& Osbourn 1960, Worthy \& Lavigne 1983, Kamalzadeh et al. 1998, Eckhardt et al. 2005, Jeanniard du Dot et al. 2009). Therefore, the South American sea lion population should have been able to revert the effects of slower growth during lactation with faster post-weaning growth rates, had the availability of offshore, pelagic prey not declined. It is also important to note that skull size reduction is unlikely to be the result of a loss of genetic variability due to overexploitation, as genetic markers have revealed no population bottleneck (M. Feijoo unpubl. data). Furthermore, the observed reduction in skull size began in the 1990s, thirty years after the cessation of sealing (Crespo \& Pedraza 1991, Reyes et al. 1999) and concomitant to the peak in landings of hake and the decline in hake stock size (Lloris et al. 2003, Koen Alonso \& Yodzis 2005). Given that the observed skull size reduction occurred in parallel with the population recovery, the overall evidence seems to indicate that industrial fishing has reduced the carrying capacity of the ecosystem off northern Patagonia for South American sea lions.

Skull size is highly correlated to body size in the South American sea lion (Rosas et al. 1993) and the CBL/SL ratio has remained invariable from 1990 to 2006. This suggests that a reduction in the skull size should have resulted in a parallel reduction in body size. Diving skills in pinnipeds are tightly linked to body size, as larger species exploit deep, benthic habitats, whereas smaller species typically behave as epipelagic predators (Gentry et al. 1986, Kooyman 1989, Costa 1991, 1993, Costa et al. 2004). Similarly, females of some highly dimorphic species have a more pelagic diet than males throughout their life, due to their smaller body size (Le Boeuf et al. 1996, 2000, Meynier et al. 2008). This suggests that the foraging habits of South American sea lions off northern Patagonia may have changed since the 1970s as a result of a decrease in body size.

Stable isotope data indicate that both sexes have become more pelagic since the 1970s (Drago et al. 2009a), in agreement with the foraging behaviour expected from a smaller body mass. The observed increase in length of the tympanic bulla in females might also be related to a higher reliance on pelagic prey in a turbid area such as northern Patagonia. This is because a larger tympanic bulla is thought to improve the underwater hearing capacity of pinnipeds, and larger bullae are expected in species consuming pelagic fish in turbid water (Hyvärinen \& Nieminen 1990).

However, the stable isotope data are also consistent with increased use of offshore prey due to the depletion of coastal resources caused by a larger sea lion population and increased discarding of undersized pelagic fish by the commercial fishery. Stable isotope data also indicate that the current diet of South American sea lions is approaching that consumed before the collapse of the population, and that dietary differences between adult males and females are vanishing (Drago et al. 2009a), which would increase intraspecific competition. Males are probably less affected than females by intraspecific competition because a larger body mass allows them to dive deeper and stay longer under water. This may explain why the reduction in skull size was less intense in males than in females, although it is unclear why the reduction affected skull width and height but not length. Whatever the reason, in this scenario of reduced carrying capacity due to competition with industrial fishing, the growth rate of the South American sea lion population in northern Patagonia is expected to decrease in the near future, unless the hake stock rebuilds.

Acknowledgements. Thanks are extended to the staff of the Marine Mammal Laboratory of the Centro Nacional Patagónico (CENPAT-CONICET), particularly to S. Ameghino, F. García, N. García, S. Leonardi, G. M. Svendsen and D. Vales for their overall assistance and field work. We thank S. L. Dans for the age assessment of the sampled individuals and C. Gambuzza for her assistance with our English. The Ministry of Education and Science (MEC) of Spain supported M.D. through a PhD fellowship. This study was funded by the Fundación BBVA through the project 'Estudio de las amenazas para la conservación de mamíferos marinos de Patagonia' (BIOCON 04), Programa Nacional de Biodiversidad, Ciencias de la Tierra y Cambio Global of the MEC of Spain through the project 'CGL2005-00922/BOS'; GEF/PNUD through the project 'Conservación de la Diversidad Biológica Marina y Prevención de la Contaminación en Patagonia' (ARG 02/018) and the Zoo d`Amneville, France. 


\section{LITERATURE CITED}

Amano M, Hayano A, Miyazaki N (2002) Geographic variation in the skull of the ringed seal, Pusa hispida. J Mammal 83:370-380

Bertolotti MI, Verazay GA, Akselman R (2001) El mar Argentino y sus Recursos Pesqueros. In: Boschi E (ed) Evolución de la flota pesquera argentina, artes de pesca y dispositivos selectivos, Vol 3. Publicaciones Especiales INIDEP, Mar del Plata

Bonner WN (1982) Seals and man: a study of interactions. Washington University Press, Seattle

Brunner S (2002) Geographic variation in skull morphology of adult Steller sea lions (Eumetopias jubatus). Mar Mamm Sci 18:206-222

Carribero A, Pérez D, Yorio P (1995) Actualización del estado poblacional del pingüino patagónico Spheniscus magellanicus en Península Valdés, Chubut, Argentina. Hornero 14:33-37

Committee on Marine Mammals (1967) Standard measurements of seals. J Mammal 48:459-462

Costa DP (1991) Reproductive and foraging energetics of pinnipeds: implications for life history patterns. In: Renouf D (ed) The behaviour of pinnipeds. Chapman \& Hall, London, p 300-344

Costa DP (1993) The secret life of marine mammals: novel tools for studying their behaviour and biology at sea. Oceanography (Wash DC) 6:120-128

Costa DP, Kuhn CE, Weise MJ, Shaffer SA, Arnould JPY (2004) When does physiology limit the foraging behaviour of freely diving mammals? Int Congr Ser 1275:359-366

Costa DP, Weise MJ, Arnould JPY (2006) Potential influences of whaling on the status and trends of pinniped populations. In: Estes JA, Demaster DP, Doak DF, Williams TM, Brownell RL (eds) Whales, whaling and ocean ecosystems. University of California Press, Berkeley, p 344-359

Crespo EA (1988) Dinámica poblacional del lobo marino de un pelo Otaria flavescens (Shaw, 1800), en el norte del Litoral Patagonico. PhD dissertation, Universidad Nacional de Buenos Aires, Buenos Aires

Crespo EA, Pedraza SN (1991) Estado actual y tendencia de la población de lobos marinos de un pelo (Otaria flavescens) en el litoral norpatagónico. Ecología Austral 1:87-95

Crespo EA, Schiavini ACM, Perez Macri G, Reyes L, Dans S (1994) Estudio sobre la determinación de edades en mamíferos marinos del Atlántico Sudoccidental. In: Oporto JA (ed) Proc IV Reunión de Trabajo de Especialistas en Mamíferos Acuáticos de América del Sur. Centro de Investigación y Manejo de Mamíferos Marinos, Valdivia, p 31-55

Crespo EA, Pedraza SN, Dans SL, Koen Alonzo M and others (1997) Direct and indirect effects of the highseas fisheries on the marine mammal populations in the northern and central Patagonian cost. J Northwest Atl Fish Sci 22: 189-207

Dans SL, Koen Alonso M, Crespo EA, Pedraza SN, García NA (2003) Interactions between marine mammals and high seas fisheries in Patagonia: an integrated approach. In: Gales N, Hindell M, Kirkwood R (eds) Marine mammals: fisheries, tourism and management issues. CSIRO Publishing, Collingwood, p 100-115

Dans SL, Crespo EA, Pedraza SN, Koen Alonso M (2004) Recovery of the South American sea lion (Otaria flavescens) population in northern Patagonia. Can J Fish Aquat Sci 61:1681-1690

Dato CV, Villarino MF, Cañete GR (2003) Dinámica de la flota comercial Argentina dirigida a la pesquería de merluza
(Merluccius hubbsi) en el mar Argentino. Período 19901997. INIDEP Informe Técnico 53:1-25

Doherty PJ (2002) Variable replenishment and the dynamics of reef fish populations. In: Sale PF (ed) Coral reef fishes. Academic Press, Burlington, MA, p 327-357

- Drago M, Crespo EA, Aguilar A, Cardona L, García N, Dans SL, Goodall N (2009a) Historic diet change of the South American sea lion in Patagonia as revealed by isotopic analysis. Mar Ecol Prog Ser 384:273-289

Drago M, Cardona L, Crespo EA, Aguilar A (2009b) Ontogenic dietary changes in South American sea lions. J Zool (Lond) 279:251-261

> Drago M, Cardona L, Aguilar A, Crespo EA, Ameghino S, García N (2010a) Diet of lactating South American sea lions, as inferred from stable isotopes, influences pup growth. Mar Mamm Sci 26:309-323

Drago M, Cardona L, García N, Ameghino S, Aguilar A (2010b) Influence of colony size on pup fitness and survival in South American sea lions. Mar Mamm Sci doi:10.1111/j.1748-7692.2010.00402.x

Eckhardt CL, Gordon-Larsen P, Adair LS (2005) Growth patterns of Filipino children indicate potential compensatory growth. Ann Hum Biol 32:3-14

Eder EB, Lewis MN (2005) Proximate composition and energetic value of demersal and pelagic prey species from the SW Atlantic Ocean. Mar Ecol Prog Ser 291:43-52

> Etnier MA (2004) Reevaluating evidence of densitydependent growth in northern fur seals (Callorhinus ursinus) based on measurements of archived skeletal specimens. Can J Fish Aquat Sci 61:1616-1626

Gentry RL, Kooyman GL, Goebel ME (1986) Feeding and diving behaviour of northern fur seals. In: Gentry RL, Kooyman GL (eds) Fur seals: maternal strategies on land and at sea. Princeton University Press, Princeton, p 61-78

Gerber LR, Hilborn R (2001) Catastrophic events and recovery from low densities in populations of otariids: implications for risk of extinction. Mammal Rev 31:131-150

Giangiobbe SM, Verazay GA, Ibáñez PM (1993) Análisis del comportamiento de la flota pesquera argentina sobre el recurso merluza durante el período 1985-1988. Frente Marit 14:23-32

Godoy JC (1963) Fauna Silvestre. Serie: Evaluación de los Recursos Naturales de la Argentina. Consejo Federal de Inversiones, Buenos Aires

> Grandi FM, Dans SL, García NA, Crespo EA (2010) Growth and age at sexual maturity of South American sea lions. Mamm Biol 75:427-436

> Hanson NN, Wurster CM, Bird MI, Reid K, Boyd IL (2009) Intrinsic and extrinsic forcing in life histories: patterns of growth and stable isotopes in male Antarctic fur seal teeth. Mar Ecol Prog Ser 388:263-272

Hixon MA, Webster MS (2002) Density dependence in reef fish populations. In: Sale PF (ed) Coral reef fishes. Academic Press, Burlington, MA, p 303-326

Hyvärinen $H$, Nieminen $M$ (1990) Differentiation of the ringed seal in the Baltic Sea, Lake Ladoga and Lake Saimaa. Finn Game Res 47:21-27

Jeanniard du Dot T, Rosen DAS, Richmond JP, Kitaysky AS, Zinn SA, Trites AW (2009) Changes in glucocorticoids, IGF-I and thyroid hormones as indicators of nutritional stress and subsequent refeeding in Steller sea lions (Eumetopias jubatus). Comp Biochem Physiol A 152: 524-534

- Kamalzadeh A, Koops WJ, van Bruchem J (1998) Feed quality restriction and compensatory growth in growing sheep: modelling changes in body dimensions. Livest Prod Sci 53: $57-67$ 
Koen Alonso M, Yodzis P (2005) Multispecies modelling of some components of the marine community of northern and central Patagonia, Argentina. Can J Fish Aquat Sci 62:1490-1512

Koen Alonso M, Pedraza SN, Crespo EA, Dans SL (1996) Análisis retrospectivo de la dinámica poblacional del lobo marino de un pelo (Otaria flavescens) en el norte de Patagonia durante el siglo XX. I Reunión Científica del Grupo Argentino de Biometría, Bahía Blanca, Argentina, p 22

Koen Alonso M, Crespo EA, García NA, Pedraza SN, Mariotti PA, Mora NJ (2002) Fishery and ontogenetic driven changes in the diet of the spiny dogfish, Squalus acanthias, in Patagonian waters, Argentina. Environ Biol Fishes 63:193-202

Kooyman GL (1989) Diverse divers: physiology and behaviour. Springer, Berlin

Le Boeuf BJ, Morris PA, Blackwell SB, Crocker DE, Costa DP (1996) Diving behavior of juvenile northern elephant seals. Can J Zool 74:1632-1644

Le Boeuf BJ, Crocker DE, Costa DP, Blackwell SB, Webb PM, Houser DS (2000) Foraging ecology of northern elephant seals. Ecol Monogr 70:353-382

Lewison RL, Crowder LB, Read AJ, Freeman SA (2004) Understanding impacts of fisheries bycatch on marine megafauna. Trends Ecol Evol 19:598-604

Lloris D, Matallanas J, Oliver P (2003) Merluzas del Mundo (Familia Merlucciidae). Catálogo comentado e ilustrado de las merluzas conocidas. FAO Catálogo de Especies para los Fines de la Pesca, No. 2. FAO, Rome

- Meynier L, Morel PCH, Chilvers BL, Mackenzie DDS, MacGibbon A, Duignan PJ (2008) Temporal and sex differences in the blubber fatty acid profiles of the New Zealand sea lion Phocarctos hookeri. Mar Ecol Prog Ser 366:271-279

Miller EH, Pitcher KW, Loughlin TR (2000) Bacular size, growth, and allometry in the largest extant otariid, the Steller sea lion (Eumetopias jubatus). J Mammal 81: 134-144

Myers RA, Worm B (2003) Rapid worldwide depletion of predatory fish communities. Nature 423:280-283

National Research Council (2002) The decline of the Steller sea lion in Alaskan waters: untangling food webs and fishing nets. Committee on the Alaska Groundfish Fishery and Steller Sea Lions, National Academy Press, Washington

Reyes L, Crespo EA, Szapkievich V (1999) Distribution and population size of the southern sea lion (Otaria flavescens)

Editorial responsibility: Michael Castellini, Alaska, USA in central and southern Chubut, Patagonia, Argentina. Mar Mamm Sci 15:478-493

Rockwood LL (2006) Introduction to population ecology. Blackwell Publishing, Oxford

Rosas FCW, Haimovici M, Pinedo MC (1993) Age and growth of the South American sea lion, Otaria flavescens (Shaw, 1800), in southern Brazil. J Mammal 74:141-147

Sanfelice D, De Freitas TRO (2008) A comparative description of dimorphism in skull ontogeny of Arctocephalus australis, Callorhinus ursinus, and Otaria byronia (Carnivora: Otariidae). J Mammal 89:336-346

Scheffer VB (1950) Growth of the testes and baculum in the fur seal, Callorhinus ursinus. J Mammal 31:384-394

> Scheffer VB (1955) Body size with relation to population density in mammals. J Mammal 36:493-515

- Scheffer VB, Wilke F (1953) Relative growth in the northern fur seal. Growth 17:129-145

> Schiavini ACM, Crespo EA, Szapkievich V (2004) Status of the population of South American sea lion (Otaria flavescens Shaw, 1800) in southern Argentina. Mamm Biol 69:108-118

Schiavini A, Yorio P, Gandini P, Raya Rey A, Boersma D (2005) Los pingüinos de las costas argentinas: estado poblacional y conservación. Hornero 20:5-23

Thompson KR (1989) An assessment of the potential for competition between seabirds and fisheries in the Falkland Islands. Falkland Islands Foundation, Brighton

Thompson D, Duck CD, McConnell BJ, Garrett J (1998) Foraging behaviour and diet of lactating female southern sea lions (Otaria flavescens) in the Falkland Islands. J Zool (Lond) 246:135-146

Trites AW (1992) Northern fur seals: Why have they declined? Aquat Mamm 18:3-18

- Trites AW, Bigg MA (1992) Changes in body growth of northern fur seals from 1958 to 1974: density effects or changes in the ecosystem? Fish Oceanogr 1:127-136

Trites AW, Donnelly CP (2003) The decline of Steller sea lions Eumetopias jubatus in Alaska: a review of the nutritional stress hypothesis. Mammal Rev 33:3-28

Wickens P, York EA (1997) Comparative population dynamics of fur seals. Mar Mamm Sci 13:241-292

Wilson PN, Osbourn DF (1960) Compensatory growth after undernutrition in mammals and birds. Biol Rev Camb Philos Soc 35:324-363

> Worthy GAJ, Lavigne DM (1983) Energetics of fasting and subsequent growth in weaned harp seal pups, Phoca groenlandica. Can J Zool 61:447-456

Submitted: July 1, 2010; Accepted: October 21, 2010

Proofs received from author(s): December 5, 2010 